\title{
In vivo methods for testing allergenicity show that high hydrostatic pressure hydrolysates of $\beta$-lactoglobulin are immunologically inert
}

\author{
I. López-Expósito, ${ }^{\star 1,2}$ R. Chicón, ${ }^{\star}$ J. Belloque, ${ }^{\star}$ R. López-Fandiño, ${ }^{\star}$ and M. C. Berin† \\ *Department of Bioactivity and Food Analysis, Instituto de Investigación en Ciencias de la Alimentación (CIAL), UAM-CSIC, Madrid, Spain \\ †Jaffe Food Allergy Institute, Mount Sinai School of Medicine, New York, NY 10029
}

\begin{abstract}
The major milk allergen $\beta$-lactoglobulin ( $\beta$-LG) exhibits an enhanced susceptibility to proteolysis under high hydrostatic pressure and this may be an efficient method to produce hypoallergenic hydrolysates. The aim of this work was to evaluate the in vivo allergenicity of $3 \beta$-LG hydrolysates produced under atmospheric pressure or high-pressure conditions. Hydrolysates were chosen based on previous experiments that showed that they provide a complete removal of intact $\beta$-LG but differed in vitro IgE-binding properties that could be traced to the peptide pattern. The ability to trigger systemic anaphylaxis was assessed using C3H/HeJ mice orally sensitized to $\beta$-LG. Outcome measures included symptom score, body temperature, serum mouse mast cell protease 1 (mMCP-1), and quantification of circulating basophils. Mast cell degranulation in vivo was assessed by passive cutaneous anaphylaxis. The 3 tested hydrolysates showed an abrogated allergenicity as revealed by the absence of anaphylactic symptoms and a decrease in body temperature. We demonstrated that the peptides present in the hydrolysates had lost their ability to cross-link 2 human IgE antibodies to induce mast cell degranulation, thus indicating that most of the peptides formed retain just one relevant IgE-binding epitope. The orally sensitized mouse model is a useful tool to address the in vivo allergenicity of novel milk formulas and demonstrates the safety of hydrolysates produced under high-pressure conditions.
\end{abstract} Key words: $\beta$-lactoglobulin, high-pressure hydrolysates, hypoallergenic, animal model

\section{INTRODUCTION}

Cow's milk protein allergy (CMA) is defined as an immunologically mediated adverse reaction to cow's

Received June 22, 2011.

Accepted September 25, 2011.

${ }^{1}$ Current address: Department of Bioactivity and Food Analysis, Instituto de Investigación en Ciencias de la Alimentación (CIAL), UAM-CSIC, 28051, Madrid, Spain.

${ }^{2}$ Corresponding author: ivan.lopez@csic.es milk protein and it is usually the first food allergy in childhood. With an incidence that ranges from 2 to $7.5 \%$ in population-based studies in different countries (Fiocchi et al., 2010), CMA often precedes the development of other food allergies, particularly egg and peanut allergies (Sicherer et al., 2010; Solinas et al., 2010). Although most children outgrow CMA by the age of $4 \mathrm{yr}$, a significant population retains the allergy for life. The general treatment for CMA is dietary and consists of eliminating milk products from the diet to avoid exposure to the implicated allergens and using hypoallergenic cow milk infant formula. To obtain a hypoallergenic formula, removal of both conformational and linear epitopes is needed (Bahna, 2008). The most common procedure to reduce allergenicity in hypoallergenic formula is protein hydrolysis. However, extensive hydrolysis causes undesirable side effects, such as poor functional and organoleptic properties, which has been attributed to the liberation of short peptides and amino acids.

On the other hand, $\beta$-LG, one of the main milk allergens, is very difficult to digest because of its high structural stability, particularly at acidic $\mathrm{pH}$. In this case, hydrolysis by proteases can be aided with physical agents, such as high hydrostatic pressure, which alters the protein structure and modulates enzyme activity (López-Fandiño, 2006; Aertsen et al., 2009). $\beta$-Lactoglobulin has been efficiently hydrolyzed by various enzymes under high pressure (Chicón et al., $2006 \mathrm{a}, \mathrm{b})$. This is because high hydrostatic pressure alters the conformational state of the protein, leading to enhanced flexibility at pressures around and above 200 MPa that increases with the pressure level and greatly favors the enzyme action (Belloque et al., 2007). As a result, and in contrast to atmospheric pressure, high pressure accelerates the first steps of proteolysis, promoting rapid disappearance of the intact protein, but leading to the accumulation of secondary proteolysis products of intermediate size, which are subsequently hydrolyzed more slowly to smaller fragments (Chicón et al., 2008a,b).

The hydrolysates obtained under high hydrostatic pressure show reduced binding to both commercial IgG 
antibodies and serum IgE of allergic patients (Bonomi et al., 2003; Peñas et al., 2006) with improved functional properties (Chicón et al., 2009). However, depending on the enzyme and pressure levels, and particularly after short hydrolysis times, $\beta$-LG hydrolysates retain some residual IgE-binding properties that can be traced to the presence of peptides that contain known $\operatorname{IgE}$ epitopes (Chicón et al., 2008a,b). It remains to be demonstrated whether these hydrolysates are hypoallergenic and whether they contain mainly peptides with just one relevant $\mathrm{IgE}$ binding epitope that might drive the immune system to a tolerant state.

Taking this into account, and considering that the peptide pattern and the immunoreactivity of the hydrolysates obtained under high pressure can be modified by the selection of the enzyme, pressure, and hydrolysis time conditions, this work evaluated the allergenicity of $3 \beta$-LG hydrolysates obtained with chymotrypsin at atmospheric pressure for $24 \mathrm{~h}$ and at $400 \mathrm{MPa}$ for $20 \mathrm{~min}$, as well as with pepsin at $400 \mathrm{MPa}$ for $5 \mathrm{~min}$. To this end, the ability of the $\beta$-LG hydrolysates to bind mouse serum-specific antibodies in vitro, to induce mast cell degranulation, and to induce anaphylactic reactions in a $\beta$-LG allergy mouse model were investigated.

\section{MATERIALS AND METHODS}

\section{Mice and Reagents}

Four- to five-week-old female $\mathrm{C} 3 \mathrm{H} / \mathrm{HeJ}$ mice were purchased from Jackson Laboratories (Bar Harbor, $\mathrm{ME}$ ). Animals were kept under specific-pathogen-free conditions. All procedures were approved by the Mount Sinai School of Medicine Institutional Animal Care and Use Committee.

BioPURE $\beta$-LG was obtained from Davisco Foods International (Eden Prairie, MN). Porcine stomach pepsin (E.C. 3.4.23.1, $570 \mathrm{U} / \mathrm{mg}$ ) and bovine pancreas chymotrypsin (EC 3.4.21.1, $55 \mathrm{U} / \mathrm{mg}$ ) were obtained from Sigma (St. Louis, MO).

\section{Preparation of Hydrolysates}

Intact and hydrolyzed $\beta$-LG were used in this study. Hydrolysates were obtained with chymotrypsin at atmospheric pressure for $24 \mathrm{~h}$ and at $400 \mathrm{MPa}$ for 20 min, as well as with pepsin at $400 \mathrm{MPa}$ for 5 min as described, respectively, in Chicón et al. (2006b) and Chicón et al. (2009). $\beta$-Lactoglobulin ( 5 g) was dissolved at a concentration of $10 \mathrm{mg} / \mathrm{mL}$ in $50 \mathrm{mM}$ Tris$\mathrm{HCl}$ buffer ( $\mathrm{pH} 6.8$ ) or $50 \mathrm{mM}$ citrate buffer ( $\mathrm{pH} 2.5$ ) for chymotrypsin or pepsin hydrolysis, respectively. The enzyme was added at an enzyme-to-substrate ratio of 1:20 (wt/wt) and the mixture was immediately subjected to proteolysis under atmospheric or high pressure at $37^{\circ} \mathrm{C}$. High-pressure treatments were performed in a Wave 6000/120 high-pressure processing unit (NC Hyperbaric, Burgos, Spain) located at the facility of IRTA (Monells, Girona, Spain). Immediately after pressure release, the enzyme was inactivated by a $\mathrm{pH}$ change ( $\mathrm{pH} 3$ for chymotrypsin and $\mathrm{pH} 6$ for pepsin). All hydrolysates were filtered using a tangent-flow ultrafiltration device through a $10-\mathrm{kDa}$ cut-off membrane. The filtrate was collected and freeze-dried. The hydrolysates were analyzed for protein content by the bicinchoninic acid (BCA) method (Pierce BCA protein assay kit; Thermo Fisher Scientific Inc., Rockford, IL) and the peptide profile was analyzed by reverse phase (RP)-HPLC as described by Chicón et al. (2006b).

\section{Sensitization and Challenge of Mice}

Five-week-old $\mathrm{C} 3 \mathrm{H} / \mathrm{HeJ}$ mice were sensitized orally with $1 \mathrm{mg}$ of native $\beta$-LG in $0.2 M$ bicarbonate buffer containing $20 \mu \mathrm{g}$ of cholera toxin (List Biologicals, Campbell, CA) on d 0, 7, 14,21, 28, and 35 by gavage. On d 42, a challenge study was performed. Mice were orally challenged with $50 \mathrm{mg}$ of $\beta$-LG or the hydrolysates and symptoms were assessed after $30 \mathrm{~min}$. Asymptomatic mice were then systemically challenged with $100 \mu \mathrm{g}$ of $\beta$-LG or hydrolysates intraperitoneally (i.p.). Severity of symptoms was assessed by body temperature using a rectal thermometer (WPI Instruments, Sarasota, FL) and by symptom score. Symptoms were scored as follows: $0=$ no symptoms; $1=$ scratching around nose and head; 2 = puffiness around eyes and mouth; $3=$ wheezing and labored respiration; $4=$ no activity after prodding (Li et al., 1999).

\section{Measurement of Antigen-Specific Immunoglobulins}

$\beta$-Lactoglobulin-specific $\operatorname{IgG}_{1}$ and $\operatorname{IgE}$ from mice serum were measured by ELISA. Briefly, 96-well plates were coated with either $\beta$-LG or the different hydrolysates $(5 \mu \mathrm{g} /$ well $)$. After an overnight incubation at $4^{\circ} \mathrm{C}$, plates were blocked with $1 \%$ BSA in PBS for $\operatorname{IgG}_{1}$ and $2.5 \%$ Tween in PBS for IgE and incubated with serial dilutions of $\beta$-LG-sensitized and naïve mice sera. Detection was performed by biotin-labeled monoclonal rat anti-mouse $\operatorname{IgG}_{1}$ or IgE (BD Pharmingen, San Diego, CA) followed by incubation with avidin-peroxidase (eBioscience, San Diego, CA). Tetramethylbenzidine was used as substrate (eBioscience).

\section{Passive Cutaneous Anaphylaxis Test}

Naïve BALB/c mice were injected intradermically in the ear pinna with $20 \mu \mathrm{L}$ of pooled sera from $\beta$-LG- 
sensitized mice (left ear) or an equal amount of pooled sera from naïve mice as controls (right ear). Twentyfour hours later, mice were injected intravenously with $100 \mu \mathrm{g}$ of either $\beta$-LG or the hydrolysates in $100 \mu \mathrm{L}$ of $1 \%$ Evan's Blue dye. One hour after injection, the mice were euthanized and the ears removed to quantify extravasation. Ears were minced and extracted overnight in $500 \mu \mathrm{L}$ of $N$-dimethylformamide (Sigma) at $55^{\circ} \mathrm{C}$. Supernatants were collected and absorbance at $655 \mathrm{~nm}$ was measured.

\section{Measurement of Mouse Mast Cell Protease 1 Levels After Challenge}

To measure mucosal mast cell activation as an indicator of anaphylaxis, serum was obtained $1 \mathrm{~h}$ after the last challenge, and mouse mast cell protease ( $\mathbf{m M C P}$ 1) levels were analyzed by ELISA according to manufacturer's instructions (Moredun Scientific, Midlothian, $\mathrm{UK})$.

\section{Detection of Circulating Basophils After Challenge}

Between 100 and $200 \mu \mathrm{L}$ of blood was collected from mice into lithium heparin-coated tubes $1 \mathrm{~h}$ after challenge. Following a washing step with PBS, cells were lysed and fixed with the Whole Blood Lysing Reagents kit according to manufacturer's instructions (Beckman Coulter, Fullerton, CA). After blocking the cells in $1 \% \mathrm{BSA}$ for $60 \mathrm{~min}$ at $23^{\circ} \mathrm{C}$, cells were stained with antibodies against CD3, CD19 (for negative gating), $\mathrm{IgE}$, and $\mathrm{CD} 49 \mathrm{~B}$ for basophil detection (all from BD Biosciences, San Jose, CA). Cells were acquired on a LSRII flow cytometer (BD Biosciences) and analyzed using FlowJo software (Tree Star, Ashland, OR).

\section{Statistical Analysis}

Analysis of variance was performed followed by a Bonferroni $t$-test for all pairwise comparisons if the data were approximately normal. $P$-values $<0.05$, based on 2 -tailed tests, were considered statistically significant. All statistical analyses were performed with GraphPad Prism (GraphPad Software Inc., La Jolla, CA).

\section{RESULTS AND DISCUSSION}

\section{Characterization of the $\beta$-LG Hydrolysates}

The conditions used to produce $\beta$-LG hydrolysates (chymotrypsin at atmospheric pressure for $24 \mathrm{~h}$, chymotrypsin at $400 \mathrm{MPa}$ for $20 \mathrm{~min}$ and pepsin at 400 $\mathrm{MPa}$ for $5 \mathrm{~min}$ ) were chosen on the basis of previous experiments that showed that they resulted in complete removal of intact $\beta$-LG but different peptide profiles (Chicón et al., 2008a,b). The RP-HPLC chromatograms of the 3 hydrolysates are shown in Figure 1.

The main differences in the peptide pattern of the hydrolysates of $\beta$-LG with chymotrypsin at atmospheric and high pressure (Figure 1A and B) were found in the

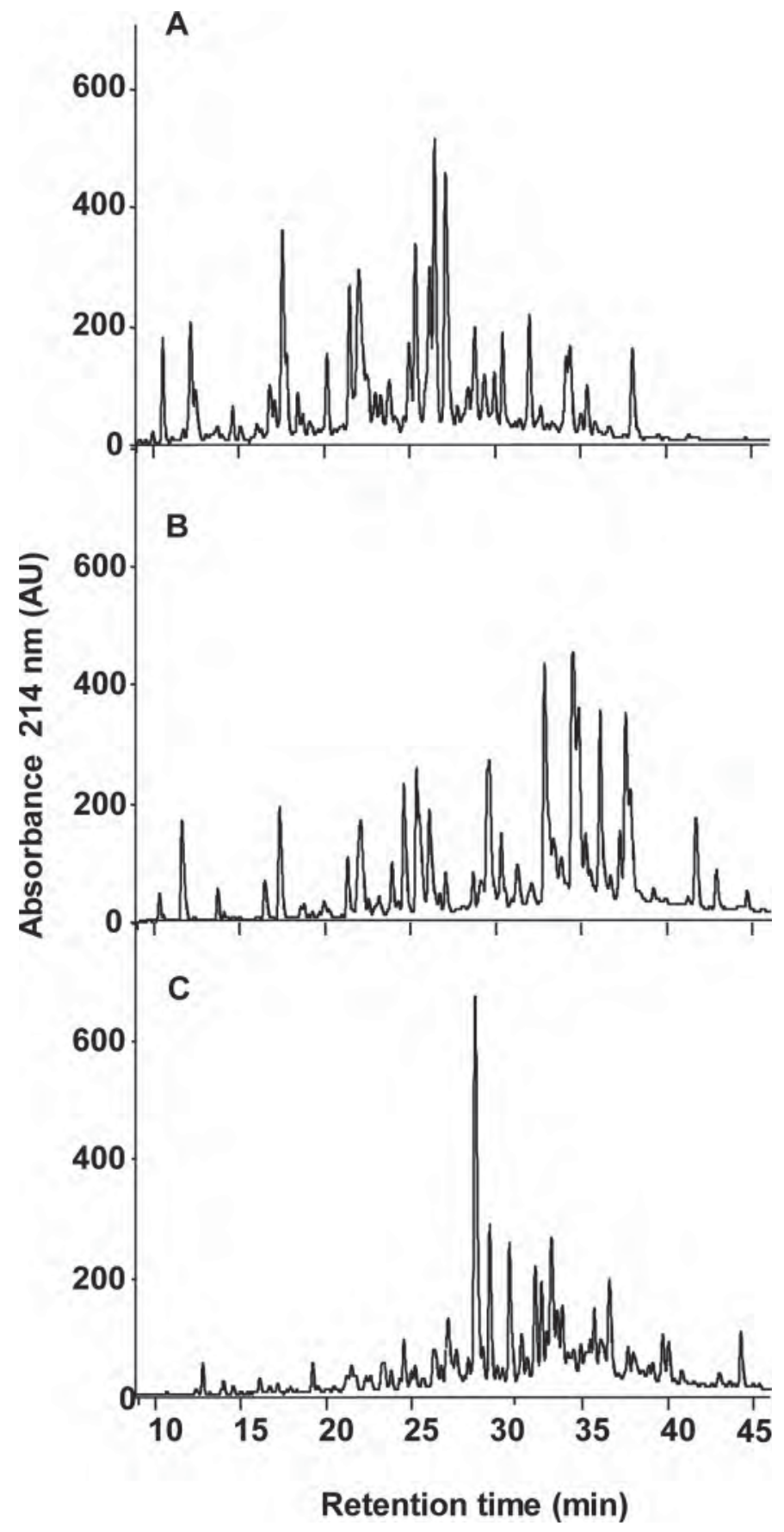

Figure 1. High performance liquid chromatography-UV chromatograms of $\beta$-LG hydrolysates obtained with chymotrypsin at atmospheric pressure for (A) $24 \mathrm{~h}$ (C24hAtm), (B) $400 \mathrm{mPa}$ for $20 \mathrm{~min}$ $(\mathrm{C} 20 \mathrm{~m} 400)$, and $(\mathrm{C})$ pepsin at $400 \mathrm{mPa}$ for $5 \mathrm{~min}(\mathrm{P} 5 \mathrm{~m} 400)$. 
RP-HPLC late eluting peaks (with retention time over 27 min in Figure 1B). In agreement with previous results (Chicón et al., 2008a), the peptides that were released to a greater extent at $400 \mathrm{MPa}$ were $\left(\mathrm{Val}_{43} \mathrm{Leu}_{57}\right)$, $\left(\mathrm{Val}_{43}-\mathrm{Gln}_{59}\right)$, $\left(\mathrm{Val}_{43}-\mathrm{Leu}_{58}\right)$, and the disulfide-linked fragments $\left(\mathrm{Lys}_{60}-\mathrm{Phe}_{82}\right) \mathrm{S}-\mathrm{S}\left(\mathrm{Ser}_{150}-\mathrm{Ile}_{162}\right),\left(\mathrm{Glu}_{62}-\mathrm{Phe}_{82}\right)$ S-S $\left(\mathrm{Ser}_{150}-\mathrm{Ile}_{162}\right),\left(\mathrm{Glu}_{62}-\mathrm{Ile}_{71}\right)$ S-S $\left(\mathrm{Ser}_{150}-\mathrm{Ile}_{162}\right)$, and $\left(\mathrm{Glu}_{62}-\mathrm{Glu}_{74}\right)$ S-S $\left(\mathrm{Ser}_{150}-\mathrm{Ile}_{162}\right)$, which were all related to the $\beta$-LG fragments $\left(\mathrm{Val}_{41}-\mathrm{Lys}_{60}\right)$ and $\left(\mathrm{Leu}_{149}-\mathrm{Ile}_{162}\right)$, identified as major IgE-binding epitopes (Sélo et al., 1999). In addition, the hydrolysate produced with chymotrypsin at $400 \mathrm{MPa}$ for $20 \mathrm{~min}$ also contained the fragments $\left(\mathrm{Ala}_{23}-\mathrm{Leu}_{32}\right)$ and $\left(\mathrm{Ser}_{21}-\mathrm{Leu}_{32}\right)$, related to the intermediate reactive epitope $\left(\mathrm{Ser}_{21}-\mathrm{Arg}_{40}\right.$; Sélo et al., 1999) and the peptides $\left(\mathrm{Val}_{123}-\mathrm{Phe}_{136}\right)$ and $\left(\mathrm{Ile}_{72^{-}}\right.$ $\mathrm{Phe}_{82}$ ), related to the $\beta$-LG sequences $\left(\mathrm{Asp}_{127}-\mathrm{Hys}_{146}\right)$ and $\left(\mathrm{Lys}_{75}-\mathrm{Ala}_{86}\right)$, which were regarded as frequently IgE-bound epitopes by Järvinen et al. (2001). The presence of these well-described epitopes in the hydrolysate obtained with chymotrypsin at $400 \mathrm{MPa}$ for $20 \mathrm{~min}$ could explain why it exhibited greater human IgE binding (from approximately 22 to $33 \%$ of that of the intact $\beta-L G)$ than the hydrolysate produced during $24 \mathrm{~h}$ at atmospheric pressure (approximately 10\% of that of the intact $\beta$-LG; Chicón et al., 2008a).

The hydrolysate obtained with pepsin at $400 \mathrm{MPa}$ for 5 min also contained intermediate peptides, with IgE epitopes (with retention time over 27 min in Figure 1C; Chicón et al., 2008b) such as $\left(\mathrm{Leu}_{95}-\mathrm{Leu}_{104}\right)$ and (Asp 96 $^{-}$ $\mathrm{Phe}_{105}$ ), which are similar to fragments $95-113$ and 97108 that have shown positive reactions with $100 \%$ of the sera from allergic patients (Ball et al., 1994; Heinzmann et al., 1999); $\left(\mathrm{Tyr}_{42}-\mathrm{Leu}_{54}\right)$ and $\left(\mathrm{Ser}_{150}-\mathrm{Ile}_{162}\right)$, which are very close to the previously mentioned $\left(\mathrm{Val}_{41}-\mathrm{Lys}_{60}\right)$ and $\left.\mathrm{Leu}_{149}-\mathrm{Ile}_{162}\right)$; or $\left(\mathrm{Ile}_{29}-\mathrm{Val}_{41}\right)$, related to the fragment 25-40 that gave a positive reaction in $72 \%$ of the allergic patients (Sélo et al., 1999). This hydrolysate also gave a positive IgE-binding response (approximately $60 \%$ of that of the intact $\beta-\mathrm{LG}$ ) higher than that of the hydrolysate obtained with chymotrypsin at $400 \mathrm{MPa}$ for 20 min and with chymotrypsin at atmospheric pressure (Chicón et al., 2008a,b). The differences found in the in vitro IgE binding suggested that the 3 hydrolysates might exhibit different immunochemical properties that could be traced to the peptide pattern.

\section{Assessment of In Vitro Antigenicity of the $\beta-L G$ Hydrolysates}

Loss of antigenicity is defined as the decrease in the capacity of antigenic determinants to interact with immunologically specific antibodies. To evaluate the antigenicity of the hydrolysates, sera from $\beta$-LG- immune and naïve mice were incubated with the different hydrolysates, as described in the Materials and Methods section, to detect the binding capacity of the protein hydrolysates to mouse immunoglobulins. All hydrolysates showed significantly reduced binding to serum from $\beta$-LG-primed mice compared with intact $\beta-\mathrm{LG}(P<0.01)$ with a minimum of an approximately $84 \%$ reduction (Figure $2 \mathrm{~A}$ ). The hydrolysates obtained with chymotrypsin at atmospheric and high pressure retained some minimal immunogenicity $(P<0.05$ compared with naïve serum at the highest dilution), whereas the hydrolysate produced with pepsin under high pressure showed no significant difference in binding to $\beta$-LG-immune serum compared with naïve serum (Figure $2 \mathrm{~B}$ ). Although reduced antigenicity is not definitive in establishing a hydrolysate as being hypoallergenic in this animal model, it is a useful initial screening tool. Further studies were performed to determine if this minimal immunogenicity would translate into allergenicity using the in vivo model.

\section{$\beta$-LG Hydrolysates Lose Their Ability to Trigger Anaphylaxis In Vivo}

To investigate whether the $\beta$-LG hydrolysates could elicit anaphylactic reactions, we used an in vivo model of experimental $\beta$-LG-induced anaphylaxis. This is of particular importance because anaphylaxis in mice may be triggered by multiple mechanisms, such as via immunoglobulin free light chains (Schouten et al., 2010) that may not be appropriately modeled by in vitro approaches. After oral challenge of $\beta$-LG-sensitized mice with $\beta$-LG at d 42, 3 of 5 mice developed systemic anaphylactic reactions (median score $2 ; P<0.05$ compared with naïve mice; Figure $3 \mathrm{~A}$ ). In contrast, when mice were orally challenged with $50 \mathrm{mg}$ of any of the hydrolysates, anaphylactic symptoms were absent in $100 \%$ of mice (median score 0). Those mice that did not show reactions to the oral challenge were rechallenged i.p. with $100 \mu \mathrm{g}$ of either intact $\beta$-LG or the hydrolysates. After the i.p. challenge, hydrolysate-challenged mice remained without symptoms and did not show significantly different symptom scores from the naïve group; however, those mice challenged with $\beta-L G$ developed severe anaphylactic reactions (median score $4 ; P<$ 0.001 compared with naïve; Figure 3C). This was associated with a significant decrease in body temperature in the mice challenged with intact $\beta$-LG but not with the hydrolysates. As shown in Figure 3D, median rectal temperature in the systemically $\beta$-LG-challenged mice was significantly lower than that of naïve mice $(34.2$ $\pm 1.0^{\circ} \mathrm{C}$ vs. $38.5 \pm 0.1^{\circ} \mathrm{C} ; P<0.001$, whereas median temperatures in the hydrolysate-challenged mice were 
not significantly different from those in naïve mice and significantly higher than in the $\beta$-LG-challenged mice $(P<0.001)$.

To determine if a subclinical mast cell activation occurred after challenge with the hydrolysates, we determined mMCP-1 levels in the serum 60 min after challenge. Mouse mast cell protease 1 is a mast cell protease released by mast cell activation within the gastrointestinal tract that exerts profound effects on intestinal epithelial barrier (McDermott et al., 2003; Forbes et al., 2008). Allergen-induced mast cell activation, as measured by serum mMCP-1 elevation, is a very sensitive measure of hypersensitivity reactions to food allergens, so that elevated mMCP-1 can be measured in allergen-challenged mice in the absence of external symptoms of anaphylaxis (Adel-Patient et al., 2005). As shown in Figure 4, serum mMCP-1 levels were markedly elevated in $\beta$-LG-challenged mice compared with naïve mice $(589.0 \pm 165.4$ vs. $10.2 \pm$ 4.6; $P<0.001)$. In contrast, serum mMCP-1 levels in the hydrolysate-challenged mice were not significantly different from those from the naïve mice.

\section{Lack of In Vivo Mast Cell Activation by $\beta$-LG Hydrolysates}

We next studied the ability of the $\beta$-LG hydrolysates to trigger mast cell degranulation in vivo using a passive cutaneous anaphylaxis (PCA) approach (Figure 5). Allergen cross-linking to allergen-specific IgE bound to the high-affinity receptor Fc $\varepsilon$ RI induces immediate degranulation of mast cells and the release of mediators that cause local extravasation. This can be measured by the localized release of intravenous Evan's Blue dye into the tissues (Xiang et al., 2006). Before the assay, the $\operatorname{IgE}$ levels in the $\beta$-LG-sensitized and naïve sera used for PCA were measured by ELISA, which showed higher IgE in $\beta$-LG-immune than in naïve sera (Figure $5 \mathrm{~A}$ ). Heat-treatment of the serum before injection abolished the PCA reaction to $\beta-\mathrm{LG}$, demonstrating the $\operatorname{IgE}$ dependence of the hypersensitivity response (data not shown). As depicted in Figure 5B, when mice were intravenously challenged with $\beta$-LG, a significant increase in extravasation was observed in the ear passively sensitized with $\beta$-LG-immune serum compared with the control ear injected with nonimmune serum. A significant decrease was observed in the extravasation measured in mice challenged with all of the hydrolysates compared with that in mice challenged with intact $\beta$-LG. When mice were challenged with the hydrolysates, extravasation did not differ significantly in the ears injected with $\beta$-LG-immune serum versus nonimmune serum, indicating that all of the hydrolysates had completely lost allergenicity in vivo. The results

\section{A}

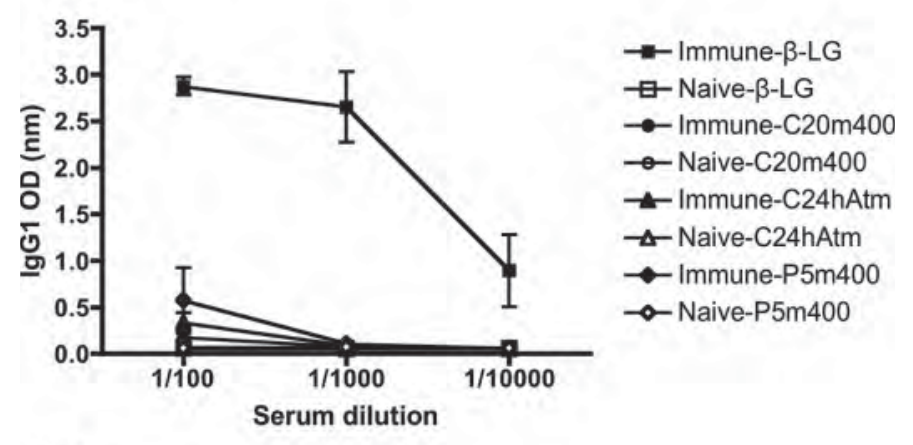

B

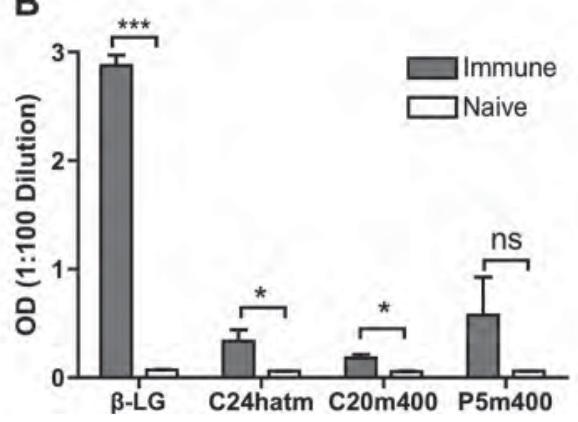

Figure 2. Immunoglobulin binding of $\beta$-LG hydrolysates. Plates were coated with intact $\beta$-LG or hydrolysates $(\mathrm{C} 20 \mathrm{~m} 400=20 \mathrm{~min}$ chymotrypsin at $400 \mathrm{MPa}, \mathrm{C} 24 \mathrm{hAtm}=24 \mathrm{~h}$ chymotrypsin at atmospheric pressure, $\mathrm{P} 5 \mathrm{~m} 400=5 \mathrm{~min}$ pepsin at $400 \mathrm{MPa}$ ). Coated plates were then exposed to serum from $\beta$-LG naïve or immune mice, and binding of IgG1 was detected. (A) Optical density (OD) values and SEM for each group by serum dilution; (B) mean and SEM of the OD for each group at the $1: 100$ sera dilution. ${ }^{*} P<0.05$; ${ }^{* * *} P<0.001$.

obtained indicate that the peptides contained in the hydrolysates were not able to cross-link IgE molecules on the surface of mast cells, probably because of the size reduction of the peptides.

\section{Basophils Disappear from Blood after Allergen Challenge}

We assessed the disappearance of basophils from the blood after allergen challenge as an additional marker of effector cell activation. We have observed that circulating basophils are extremely sensitive to allergen challenge in sensitized mice, and $\beta$-LG challenge of $\beta$-LG-sensitized mice led to a complete disappearance of $\mathrm{CD}_{4} \mathrm{~b}^{+} \mathrm{IgE}^{+}$cells in the circulation (Figure 6). However, circulating basophils were completely unaffected by challenge of the $\beta$-LG-sensitized mice with any of the hydrolysates. This method represents a new approach to evaluate effector cell activation by food allergens in mice, but more research needs to be done to elucidate the mechanisms responsible for the loss of circulating basophils. It has been shown in lupus patients with autoreactive IgE that basophils have an activated 

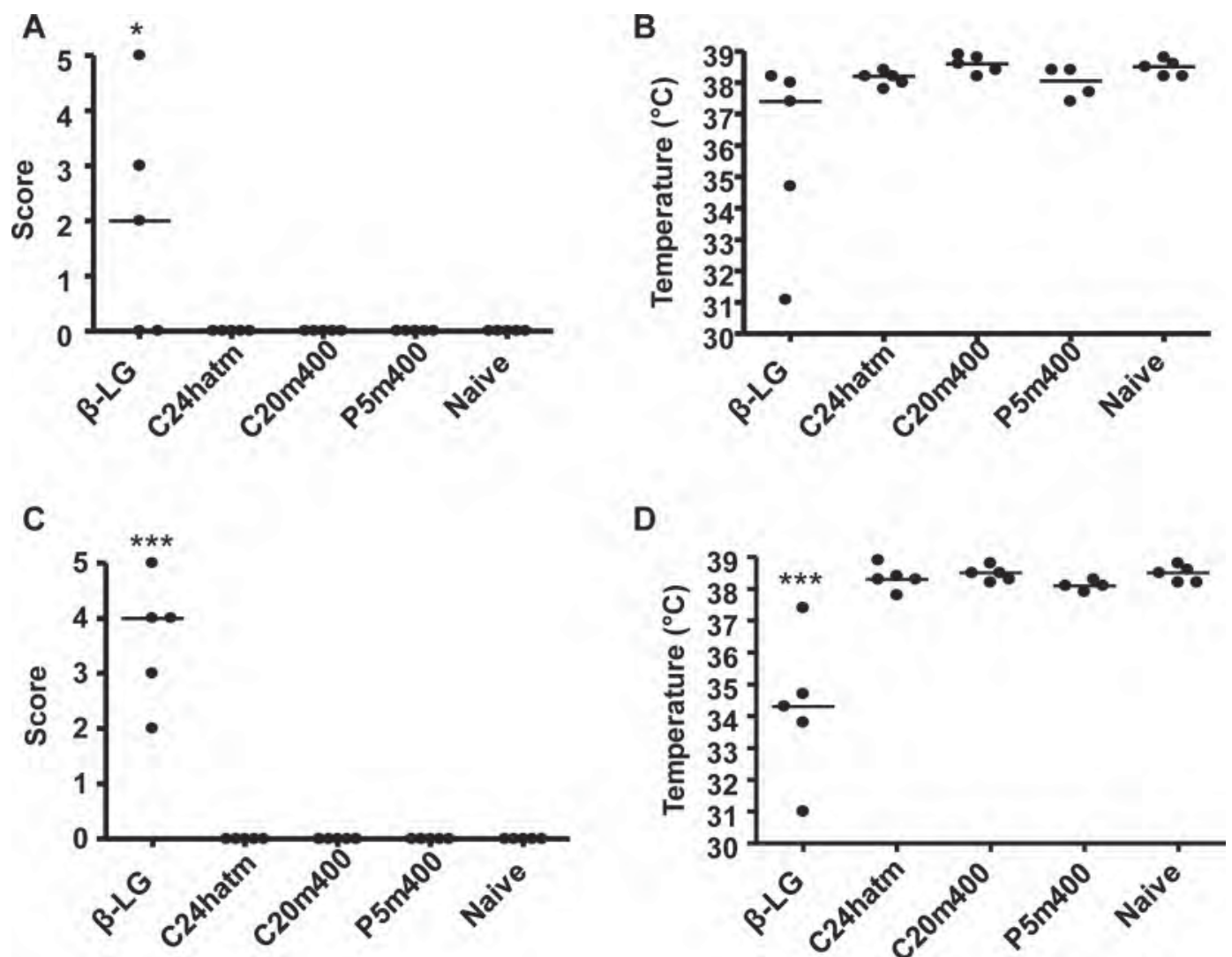

Figure 3. Systemic anaphylaxis. Mice were orally sensitized to $\beta$-LG and then orally challenged (A, B) with $50 \mathrm{mg}$ of intact $\beta$-LG or hydrolysates $(\mathrm{C} 20 \mathrm{~m} 400=20 \mathrm{~min}$ chymotrypsin at $400 \mathrm{MPa}, \mathrm{C} 24 \mathrm{hAtm}=24 \mathrm{~h}$ chymotrypsin at atmospheric pressure, $\mathrm{P} 5 \mathrm{~m} 400=5 \mathrm{~min}$ pepsin at $400 \mathrm{MPa}$ ), followed by intraperitoneal challenge (C, D) with $100 \mu \mathrm{g}$ of $\beta$-LG or hydrolysates. Symptom score (A, C) was measured as outlined in methods, and body temperature $(\mathrm{B}, \mathrm{D})$ was measured with rectal thermometer $30 \mathrm{~min}$ after oral and intraperitoneal challenge. ${ }^{*} P<0.05$; $* * * P<0.001$ compared with naïve mice.

phenotype, express the lymph node homing molecule CD62L, are reduced in number in the peripheral blood, and can be localized in the lymph nodes (Charles et al., 2010). Therefore, we speculate that basophil activation after anaphylaxis leads to a redistribution and homing of basophils to the lymph nodes or peripheral tissues, where they can influence the adaptive immune response (Sokol and Medzhitov, 2010)

\section{CONCLUSIONS}

This study showed the lack of allergenicity of 3 $\beta$-LG hydrolysates by using an in vivo approach for the assessment of allergenicity. The in vivo approach included an evaluation of clinical signs of anaphylaxis and objective measurements of IgE-dependent mast cell and basophil activation. Our results support the usefulness of the orally sensitized mouse model for testing residual allergenicity of milk formulas before testing in humans. Furthermore, the disappearance of circulating basophils after allergen challenge might be an effective marker of effector cell activation after allergen chal- lenge. Proteolysis of the milk whey protein $\beta$-LG under high hydrostatic pressure can yield safe protein hydrolysates. Under atmospheric pressure conditions, removal

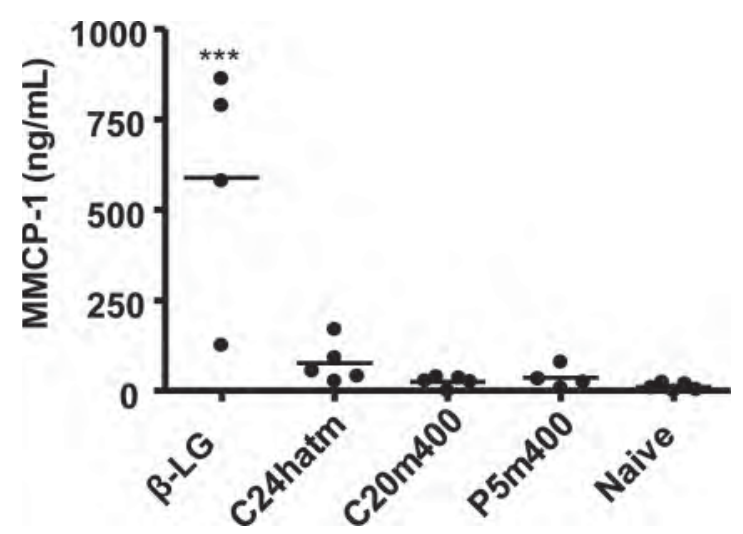

Figure 4. Mucosal mast cell activation. Mice were orally sensitized to $\beta$-LG and then challenged with intact $\beta$-LG or hydrolysates $(\mathrm{C} 20 \mathrm{~m} 400=20 \mathrm{~min}$ chymotrypsin at $400 \mathrm{MPa}, \mathrm{C} 24 \mathrm{hAtm}=24 \mathrm{~h}$ chymotrypsin at atmospheric pressure, $\mathrm{P} 5 \mathrm{~m} 400=5 \mathrm{~min}$ pepsin at 400 $\mathrm{MPa})$. Sixty minutes after challenge, sera were obtained, and $\mathrm{mMCP}-$ 1 was measured by ELISA. $* * * P<0.001$ compared with naïve mice. 
A

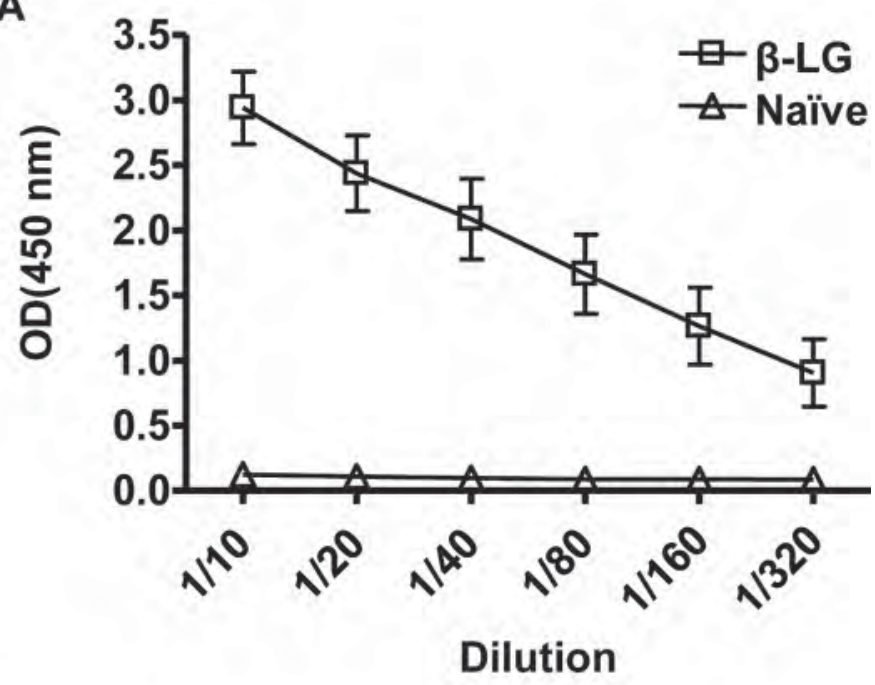

A

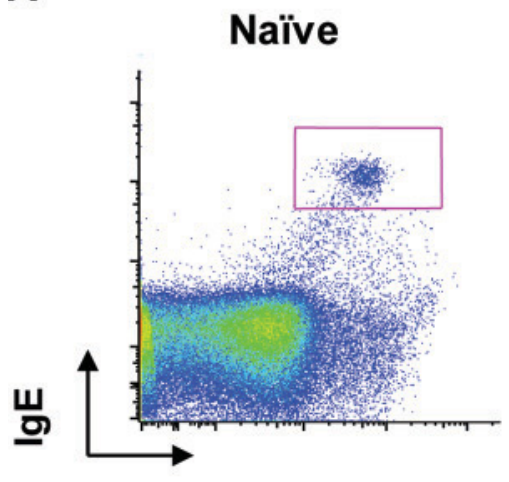

$\beta$-lactoglobulin

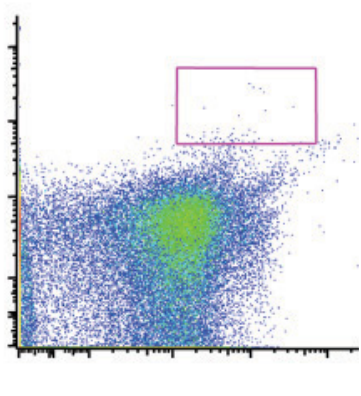

CD49B
B

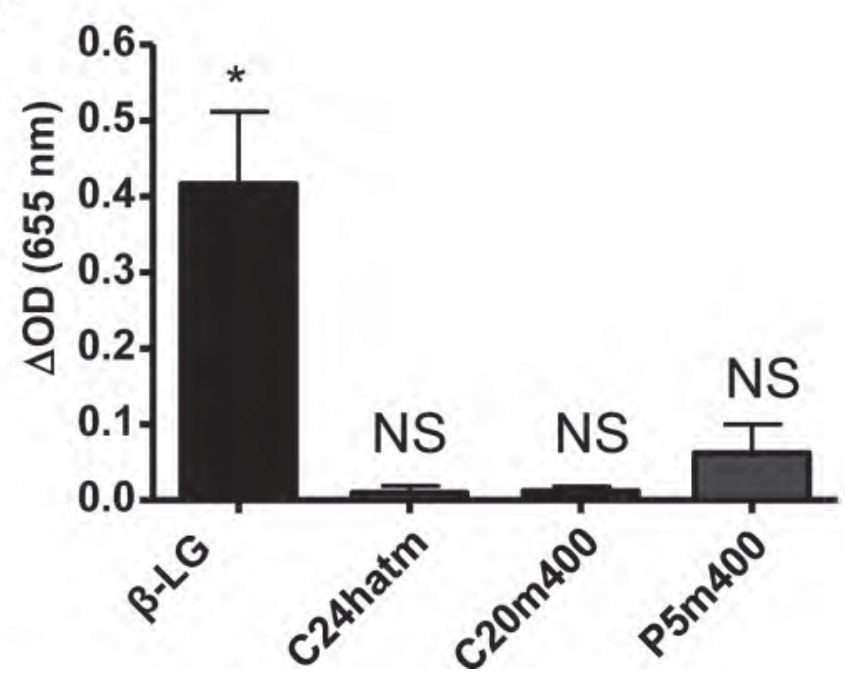

Figure 5. Passive cutaneous anaphylaxis: (A) $\beta$-LG-specific IgE was measured in a pool of serum from $\beta$-LG immune or naive mice by ELISA, and expressed as optical density by serum dilution; (B) serum from $\beta$-LG immune or naïve mice was injected into the ears of mice before intravenous injection with Evans blue together with intact $\beta$-LG or the hydrolysates $(\mathrm{C} 20 \mathrm{~m} 400=20$ min chymotrypsin at $400 \mathrm{MPa}$, $\mathrm{C} 24 \mathrm{hAtm}=24 \mathrm{~h}$ chymotrypsin at atmospheric pressure, $\mathrm{P} 5 \mathrm{~m} 400=5$ min pepsin at $400 \mathrm{MPa}$ ). After $60 \mathrm{~min}$, the ears were removed, dye was extracted, and absorbance measured at $655 \mathrm{~nm}$. Data are expressed as the difference between the ears injected with immune or naïve sera. ${ }^{*} P$ $<0.05$ comparing immune and naïve ears.

of intact $\beta$-LG takes hours using chymotrypsin and it is not possible with pepsin. However, high hydrostatic pressure yields, in a few minutes, hydrolysates that do not contain intact protein and exhibit better functional properties because they contain large, hydrophobic peptides. Antibody binding in vitro against both human $\operatorname{IgE}$ and mouse $\operatorname{IgG}_{1}$ showed residual antigenicity in the peptides produced under high pressure because

\section{B}

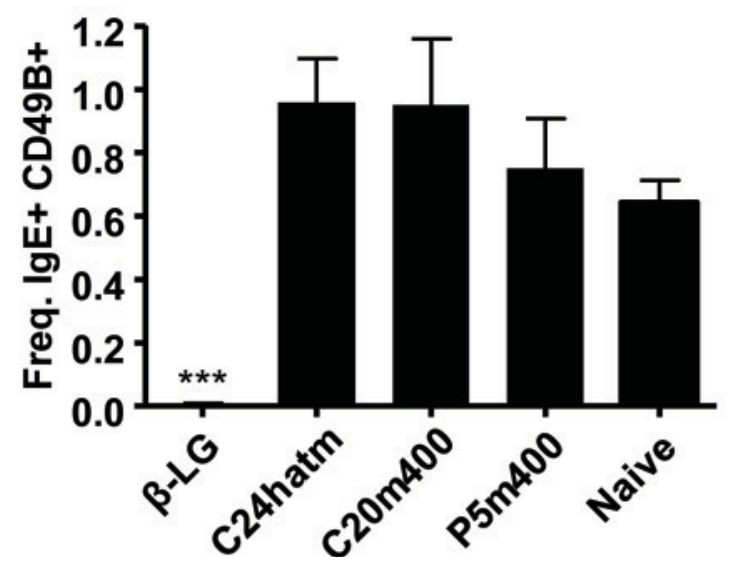

Figure 6. Blood basophil detection: mice were orally sensitized to $\beta$-LG and then challenged with intact $\beta$-LG or hydrolysates (C20m400 $=20$ min chymotrypsin at $400 \mathrm{MPa}, \mathrm{C} 24 \mathrm{hAtm}=24 \mathrm{~h}$ chymotrypsin at atmospheric pressure, P5m400 = 5 min pepsin at $400 \mathrm{MPa}$ ). Sixty minutes after challenge, blood was obtained and cells stained for flow cytometric detection of basophils. (A) Representative dot plot showing a distinct population of $\mathrm{CD}_{4} 4 \mathrm{~b}^{+} \mathrm{IgE}^{+}$basophils in the circulation of naïve mice after $\beta$-LG challenge (left panel). This population was absent in $\beta$-LG-sensitized mice after $\beta$-LG challenge (right panel); (B) quantification of blood basophils as a percentage of non-CD19/CD3positive cells. $*^{* *} P<0.001$ compared with naïve mice. Color version available in the online PDF.

of the presence of allergenic epitopes. However, the lack of allergenicity of the hydrolysates (as revealed by the absence of anaphylactic symptoms, reduction in body temperature, and the demonstration that the peptides present had lost their ability to cross-link 2 human $\operatorname{IgE}$ antibodies to induce mast cell degranulation) indicates that most of the peptides formed retain just one relevant IgE binding epitope that could help the immune system to develop tolerance to milk proteins. 


\section{ACKNOWLEDGMENTS}

The authors acknowledge financial aid to projects AGL2008-01740 [Spanish Ministry for Science and Innovation (MICIIN), Spain], P2009/AGR-1469 [Comunidad de Madrid (CAM), Spain], and CONSOLIDERINGENIO 2007-00063 (MICIIN). The authors acknowledge B. Miralles (Instituto de Investigación en Ciencias de la Alimentación, Madrid, Spain) for her technical assistance.

\section{REFERENCES}

Adel-Patient, K., H. Bernard, S. Ah-Leung, C. Créminon, and J. M Wal. 2005. Peanut- and cow's milk-specific IgE, Th2 cells and local anaphylactic reaction are induced in Balb/c mice orally sensitized with cholera toxin. Allergy 60:658-664.

Aertsen, A., F. Meersman, M. E. Hendrickx, R. F. Vogel, and C. W. Michiels. 2009. Biotechnology under high pressure: Applications and implications. Trends Biotechnol. 27:434-441.

Bahna, S. L. 2008. Hypoallergenic formulas: Optimal choices for treatment versus prevention. Ann. Allergy Asthma Immunol. 101:453459.

Ball, G., M. J. Shelton, B. J. Walsh, D. Hill, C. S. Hosking, and M. E. H. Howden. 1994. A major continuous epitope of bovine $\beta$-lactoglobulin recognized by human IgE binding. Clin. Exp. Allergy 24:758-764.

Belloque, J., R. Chicón, and R. López-Fandiño. 2007. Unfolding and refolding of $\beta$-lactoglobulin subjected to high hydrostatic pressure at different $\mathrm{pH}$ values and temperatures and its influence on proteolysis. J. Agric. Food Chem. 55:5282-5288.

Bonomi, F., A. Fiocchi, H. Frøkiaer, A. Gaiaschi, S. Iametti, C. Poiesi, P. Rasmussen, P. Restani, and P. Rovere. 2003. Reduction of immunoreactivity of bovine beta-lactoglobulin upon combined physical and proteolytic treatment. J. Dairy Res. 70:51-59.

Charles, N., D. Hardwick, E. Daugas, G. G. Illei, and J. Rivera. 2010. Basophils and the T helper 2 environment can promote the development of lupus nephritis. Nat. Med. 16:701-707.

Chicón, R., J. Belloque, E. Alonso, and R. López-Fandiño. 2009. Antibody binding and functional properties of whey protein hydrolysates obtained under high pressure. Food Hydrocolloids 23:593599.

Chicón, R., J. Belloque, E. Alonso, P. J. Martín-Alvarez, and R. López-Fandiño. 2008a. Hydrolysis under high hydrostatic pressure as a means to reduce the binding of beta-lactoglobulin to immunoglobulin E from human sera. J. Food Prot. 71:1453-1459.

Chicón, R., J. Belloque, I. Recio, and R. López-Fandiño. 2006a. Influence of high hydrostatic pressure on the proteolysis of betalactoglobulin A by trypsin. J. Dairy Res. 73:121-128.

Chicón, R., R. López-Fandiño, E. Alonso, and J. Belloque. 2008b. Proteolytic pattern, antigenicity, and serum immunoglobulin E binding of beta-lactoglobulin hydrolysates obtained by pepsin and high-pressure treatments. J. Dairy Sci. 91:928-938.

Chicón, R., R. López-Fandiño, A. Quirós, and J. Belloque. 2006b. Changes in chymotrypsin hydrolysis of beta-lactoglobulin $\mathrm{A}$ induced by high hydrostatic pressure. J. Agric. Food Chem. 54:2333-2341.
Fiocchi, A., J. Brozek, H. Schünemann, S. L. Bahna, A. von Berg, K. Beyer, M. Bozzola, J. Bradsher, E. Compalati, M. Ebisawa, M. A. Guzman, H. Li, R. G. Heine, P. Keith, G. Lack, M. Landi, A. Martelli, F. Rancé, H. A. Sampson, A. Stein, L. Terracciano, and S. Vieths. 2010. World Allergy Organization (WAO) Diagnosis and Rationale for Action against Cow's Milk Allergy (DRACMA) Guidelines. Pediatr. Allergy Immunol. 21:1-125.

Forbes, E. E., K. Groschwitz, J. P. Abonia, E. B. Brandt, E. Cohen, C. Blanchard, R. Ahrens, L. Seidu, A. McKenzie, R. Strait, F. D. Finkelman, P. S. Foster, K. I. Matthaei, M. E. Rothenberg, and S. P. Hogan. 2008. IL-9- and mast cell-mediated intestinal permeability predisposes to oral antigen hypersensitivity. J. Exp. Med. 205:897-913.

Heinzmann, A., S. Blattmann, P. Spuergin, J. Forster, and K. A. Deichmann. 1999. The recognition pattern of sequential B cell epitopes of $\beta$-lactoglobulin does not vary with the clinical manifestations of cow's milk allergy. Int. Arch. Allergy Immunol. 120:280-286.

Järvinen, K. M., P. Chatchatee, L. Bardina, K. Beyer, and H. A. Sampson. 2001. IgE and IgG binding epitopes on $\alpha$-lactalbumin and $\beta$-lactoglobulin in cow's milk allergy. Int. Arch. Allergy Immunol. 126:111-118.

Li, X. M., B. H. Schofield, C. K. Huang, G. I. Kleiner, and H. A Sampson. 1999. A murine model of IgE-mediated cow's milk hypersensitivity. J. Allergy Clin. Immunol. 103:206-214.

López-Fandiño, R. 2006. Functional improvement of milk whey proteins induced by high hydrostatic pressure. Crit. Rev. Food Sci. Nutr. 46:351-363.

McDermott, J. R., R. E. Bartram, P. A. Knight, H. R. Miller, D. R. Garrod, and R. K. Grencis. 2003. Mast cells disrupt epithelial barrier function during enteric nematode infection. Proc. Natl. Acad. Sci. USA 100:7761-7766.

Peñas, E., P. Restani, C. Ballabio, G. Préstamo, A. Fiocchi, and R. Gomez. 2006. Evaluation of the residual antigenicity of dairy whey hydrolysates obtained by combination of enzymatic hydrolysis and high-pressure treatment. J. Food Prot. 69:1707-1712.

Schouten, B., B. C. van Esch, A. O. van Thuijl, B. R. Blokhuis, T. Groot Kormelink, G. A. Hofman, G. E. Moro, G. Boehm, S. Arslanoglu, A. B. Sprikkelman, L. E. Willemsen, L. M. Knippels, F. A. Redegeld, and J. Garssen. 2010. Contribution of IgE and immunoglobulin free light chain in the allergic reaction to cow's milk proteins. J. Allergy Clin. Immunol. 125:1308-1314.

Sélo, I., G. Clément, H. Bernard, J. M. Chatel, C. Créminon, G. Peltre, and J. M. Wal. 1999. Allergy to bovine $\beta$-lactoglobulin: Specificity of human IgE to tryptic peptides. Clin. Exp. Allergy 29:1055-1063.

Sicherer, S. H., R. A. Wood, D. Stablein, A. W. Burks, A. H. Liu, S. M. Jones, D. M. Fleischer, D. Y. Leung, A. Grishin, L. Mayer, W. Shreffler, R. Lindblad, and H. A. Sampson. 2010. Immunologic features of infants with milk or egg allergy enrolled in an observational study (Consortium of Food Allergy Research) of food allergy. J. Allergy Clin. Immunol. 125:1077-1083.

Sokol, C. L., and R. Medzhitov. 2010. Role of basophils in the initiation of Th2 responses. Curr. Opin. Immunol. 22:73-77.

Solinas, C., M. Corpino, R. Maccioni, and U. Pelosi. 2010. Cow's milk protein allergy. J. Matern. Fetal Neonatal Med. 23:76-79.

Xiang, Z., C. Möller, and G. Nilsson. 2006. Readministration of IgE is required for repeated passive cutaneous anaphylaxis in mice. Int. Arch. Allergy Immunol. 141:168-171. 